\title{
Predictors of ante-natal care, delivery and infant feeding practices among rural women in Madhya Pradesh, India
}

\section{Indrapal Ishwarji Meshram, Kodavanti Mallikharjun Rao, Chitty Gal Reddy, Kakani Sreerama Krishna, Kodali Venkaiah, Avula Laxmaiah, Ginnela Narasimhachary Veera Brahmam}

Division of Community Studies, NIN, ICMR, Hyderabad, Andhra Pradesh

Address for the Correspondence: Dr. Avula Laxmaiah, Scientist ' $F$ ', Division of Community Studies, ICMR, Hyderabad-500007, Andhra Pradesh.

E-mail: avulalaxman@yahoo.com

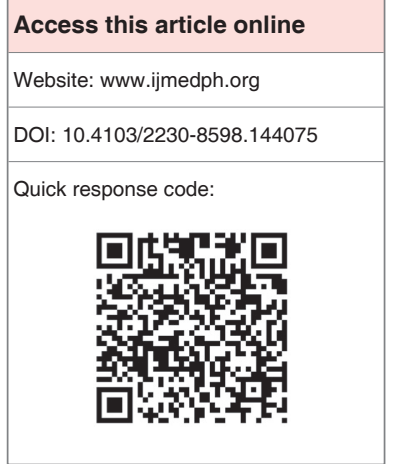

Background: Maternal and infant mortality rates and prevalence of under nutrition are high in the State Madhya Pradesh. Regular ante-natal check-ups (ANC), delivery by trained health personnel, delivery practices and optimal infant feeding practices are important to reduce maternal and infant mortality. Objectives: The aim was to assess antenatal care, delivery and infant feeding practices of mothers of <1-year-old children in Madhya Pradesh. Materials and Methods: This was community-based cross-sectional study carried out in the rural areas of Madhya Pradesh by adopting systematic random sampling procedure. Data were collected from 5324 mothers having < 1-year-old children. Information on household $(\mathrm{HH})$ socioeconomic and demographic particulars was collected from the mothers. Bivariate and multivariate analysis was performed to study the association between dependent and independent variables. Results and Interpretations: About 36\% mothers had undergone at least three ante-natal check-ups and $73 \%$ delivered either at government or private hospitals. Only $26 \%$ mothers initiated breastfeeding within 1-h of birth and $92 \%$ fed colostrum. Step-wise regression analysis showed that ante-natal care for $<3$ times was significantly $(P<0.01)$ higher among women with high parity $(\geq 5)$, illiterate women, and among lower socioeconomic group, s while home delivery was higher among women with high parity $(\geq 5)$ (odds ratio [OR]: 2.3), among Scheduled Caste and Tribe women (OR: 1.5), illiteracy of head of $\mathrm{HH}$ (OR: 2), and among lower socioeconomic groups (OR: 1.3). Discarding colostrum was higher among illiterate women (OR: 1.6), belonging to lower socioeconomic groups (OR: 1.4) and delivery conducted by untrained person (OR: 3.9), while initiation of breastfeeding after 1 -h of childbirth was higher among $\geq 30$ years women (OR: 1.9), illiterate women (OR: 1.4), and delivery by untrained person (OR: 2.9). Conclusions: It was observed that antenatal care, delivery and infant and young child feeding practices were associated with type of community, literacy status of mother, wealth index and person conducting delivery. Hence improving the literacy mothers, delivery by trained person and increasing awareness about optimal infant feeding practices will help to reduce infant and maternal mortality.

Key words: Ante-natal care, breastfeeding, complementary feeding, delivery practices

\section{INTRODUCTION}

An appropriate ante-natal care practices and optimal infant and young child feeding (IYCF) practices play an important role in child survival and maternal health. Nutritional status during pregnancy determines the health and nutritional status of the offspring. ${ }^{[1]}$ Healthy mother gives birth to healthy child and maternal under nutrition results in low birth weight of the infant. National population policy 2000 stated that all the pregnant mothers should receive at least three ante-natal check-ups (ANC) during pregnancy, and 100\% deliveries should be institutional. ${ }^{[2]}$

According to National Family Health Survey (NFHS), only 41\% pregnant mothers had undergone at least three ANCs; (35\% in rural areas), and only 12\% consumed iron and folic acid tablets (IFA) tablets for $\geq 90$ days in Madhya Pradesh. ${ }^{[3]}$ Only 17\% were institutional deliveries, while $83 \%$ delivered at home, most of the deliveries were conducted by trained birth attendants $(55.7 \%)$. 
Madhya Pradesh is one of the economically backward State in India with highest maternal (269/1 lakh live births) and infant mortality (67/100 live births). The Millennium Development Goals of the United Nations, aimed at achieving 109 maternal deaths/lakh of live births and 28 infant deaths/100 live births by 2015 . As per current statistics, Madhya Pradesh is still far to achieve these goals. ${ }^{[4]}$

Evidence available showed that the optimal use of maternal health services helps in reducing maternal morbidity and mortality. However, the utilization of these services is a complex phenomenon influenced by many factors. Various studies conducted world-wide ${ }^{[5-8]}$ and in India ${ }^{[9,10]}$ have recognized socioeconomic factors and service delivery environment as important determinants of maternal health.

Poor feeding practices during infancy and early childhood, resulting in under nutrition, impaired cognitive and mental development, poor school performance and reduced productivity in later life.

Studies have showed that use of antenatal care and IYCF practices are strongly correlated with demographic and socioeconomic characteristics. ${ }^{[1,12]}$

Government of Madhya Pradesh is planning to implement district level special nutrition intervention program to improve the nutritional status of under 5 years children. Therefore, the present study was carried out by National Institute of Nutrition (NIN), Hyderabad during 2010-11 in rural areas of Madhya Pradesh, India. The study identifies the factors associated with ANC practices, place of delivery, colostrum's feeding and time of initiation of breastfeeding. Data pertaining to $<1$-year children is presented in this communication.

\section{MATERIALS AND METHODS}

The study was carried out during March 2011 to August 2011. The study was approved by the Institutional Ethical Review Board and also Scientific Advisory Committee of NIN, Hyderabad. Written informed consent was obtained from the mothers involved in the study.

\section{Sampling design}

This was a community-based cross-sectional study carried out in all the districts of Madhya Pradesh State by adopting systematic random sampling procedure.

\section{Selection of villages}

For the purpose of the survey, in each district, a total of 20 villages were selected, using systematic random procedure, covering all the taluks/blocks based on "population proportional to size" of the village.

\section{Selection of households}

In each of the selected villages, a total of 20 households (HHs) were covered. For this purpose, the main village and its hamlets, if any, were divided into five geographical areas, based on natural group of $\mathrm{HHs} /$ streets/mohallas/areas, etc. HHs belonging to Scheduled Caste and Scheduled Tribe (SC/ST) communities generally formed one group. From each of these groups, four consecutive $\mathrm{HHs}$ having at least one <5-year-old child were surveyed by selecting a random start, starting from the Northeast corner of the area. However, in the selected $\mathrm{HH}$, all the children were included in the study.

\section{Data collection}

Information on $\mathrm{HH}$ socioeconomic and demographic particulars were collected in the selected HHs, using a precoded and pretested questionnaire. Following information was obtained from all the mothers interviewed.

\section{Maternal particulars and ante-natal care}

Maternal particulars such as maternal age, parity, utilization of antenatal care (ANC), tetanus toxoid immunization, receipt of IFA tablets, and particulars of delivery was collected.

\section{Infant and young child feeding practices}

Infant and young child feeding practices like time of initiation of breastfeeding, prelacteal and colostrum feeding, exclusive breastfeeding and age at complementary feeding (CF) in terms of age of initiation, type and frequency of $\mathrm{CF}$ was assessed by administering precoded, validated questionnaires. In addition, information on sociocultural aspects of IYCF practices by mothers of $<3$ years children were collected.

\section{Training and standardization}

Teams consisting of two postgraduate Research Assistants (Nutritionist/Anthropologist/Social worker) and one graduate field investigator having proficiency in local language were recruited, trained and standardized in various survey methodologies, by the scientists from the institute. All the survey instruments were developed, translated into local (Hindi) vernacular, validated and pretested before used.

Household wealth was assessed by using principal components analysis. HH socioeconomic and demographic variables such as type of house, occupation of parents, per capita income, type of cooking fuel, electricity, sanitary latrine and separate kitchen were included in the factor analysis. The first component explained about $43 \%$ of the variance in the observed set of variables included all the variables. The regression scores from the first component were used to create an index that was divided into tertiles. This was chosen in line with Filmer and Prichett's. ${ }^{[13,14]}$

\section{Data analysis}

The data were scrutinized and entered into the computers at NIN. The data cleaning was done by carrying out range and consistency checks. Descriptive and analytical statistics of the data were carried out using SPSS Windows version 17.0. ${ }^{[15]}$ 
Bivariate and multivariate analysis was carried out using logistic regression model. Those independent variables found to be significant in the bivariate analysis were included in a multivariate regression model for each dependent variable. The results were expressed as odds ratio (OR) with 95\% confidence interval (CI).

\section{Dependent variables}

Four dependent variables were used for analysis, that is ANC during pregnancy, place of delivery, colostrum feeding and time of initiation of breastfeeding. For ANC, women who had at least three ANC during last pregnancy were coded as " 0 ," and $<3$ ANC and those not undergone ANC as " 1 ," institutional deliveries were coded as " 0 ," and home deliveries as " 1 ." Colostrum feeding was coded as " 0 " and discarded colostrum as " 1 ," while initiation of breastfeeding within 1 -h of birth was coded as " 0 " and after 1-h of birth as " 1 ."

\section{Independent variables}

Independent variables included in the analysis were age, parity, community, type of family, literacy status, wealth index (as tertiles), while place of delivery and delivery conducted by were added in the analysis of IYCF practices along with above variables.

\section{RESULTS}

\section{Coverage particulars}

About 2104 mothers are having $<6$ months children and 3352 mothers of 6-11 months children were interviewed for the present study. Mean age of the mother was 24.9 years (standard deviation 3.79, range: $17-45$ years) [Table 1].

\section{Breast feeding practices}

Only one-fourth $(26 \%)$ mothers initiated breastfeeding within 1-h of birth, about $92 \%$ fed colostrum to the newborn, about $78 \%$ had undergone antenatal check-up during last pregnancy, while $36 \%$ had undergone at least three ANCs and 73\% mothers delivered in health institutions [Table 2].

\section{Factors affecting ante-natal care and place of delivery}

The sociodemographic factors associated with ante-natal checkup and delivery practices are given in Table 3. On bivariate analysis, it was observed that increasing age and parity of women, belonging to SC/ST communities, living in nuclear families, illiteracy of self and husband, and lower wealth index were significantly associated with ANCs for $<3$ times and home deliveries.

On multivariate analysis, it was observed that the risk of undergoing $<3$ ANC during pregnancy was significantly $(P<0.01)$ higher among women with higher parity $(\geq 5)(\mathrm{OR}=2.5,1.41-4.49)$, among women living in nuclear families $(\mathrm{OR}=1.4,1.07-1.61)$, among illiterate women $(\mathrm{OR}=2.3, \mathrm{CI}=1.82-2.95)$ and among women belonging to lower socioeconomic status (SES) (OR = 1.3, 1.01-1.62). Risk of home delivery was significantly higher among women with high parity $(\geq 5)(\mathrm{OR}=2.3,1.80-2.93)$, among women belonging to SC/ ST communities $(\mathrm{OR}=1.5,1.21-1.97)$, illiteracy of head of HHs $(\mathrm{OR}=2.0,1.38-2.87)$ and among women belonging to lower SES $(\mathrm{OR}=1.7,1.42-1.2 .04)[$ Table 4].

\section{Factors affecting colostrum feeding and time of initiation of breastfeeding}

The sociodemographic factors, and delivery practices associated with colostrum feeding and time of initiation of breastfeeding is given in

\begin{tabular}{|c|c|c|}
\hline Particulars & $n$ & Percentage \\
\hline \multicolumn{3}{|l|}{ Age } \\
\hline $17-25$ & 3380 & 62.0 \\
\hline $26-30$ & 1431 & 26.2 \\
\hline$\geq 30$ & 644 & 11.8 \\
\hline \multicolumn{3}{|l|}{ Parity } \\
\hline 1 & 2095 & 38.4 \\
\hline 2 & 1706 & 31.3 \\
\hline 3 & 937 & 17.2 \\
\hline 4 & 398 & 7.3 \\
\hline$\geq 5$ & 320 & 5.8 \\
\hline \multicolumn{3}{|l|}{ Community } \\
\hline$S C+S T$ & 2612 & 47.9 \\
\hline $\mathrm{OBC}$ & 2199 & 40.3 \\
\hline Others & 646 & 11.8 \\
\hline \multicolumn{3}{|l|}{ Type of family } \\
\hline Nuclear & 2434 & 44.6 \\
\hline Extended nuclear & 779 & 14.3 \\
\hline Joint & 2244 & 41.1 \\
\hline \multicolumn{3}{|l|}{ Literacy status } \\
\hline Illiterate & 2676 & 49.0 \\
\hline $1^{\text {st }}-7^{\text {th }}$ class & 1334 & 24.5 \\
\hline $8^{\text {th }}$ and above & 1447 & 26.5 \\
\hline \multicolumn{3}{|c|}{ Literacy status of head of $\mathrm{HH}$} \\
\hline Illiterate & 1613 & 29.6 \\
\hline $1^{\text {st }-7^{\text {th }} \text { class }}$ & 1154 & 21.1 \\
\hline $8^{\text {th }}-10^{\text {th }}$ class & 2379 & 43.6 \\
\hline Inter and above & 311 & 5.7 \\
\hline \multicolumn{3}{|c|}{ Major occupation of a woman } \\
\hline Labor & 1420 & 26.0 \\
\hline Service/business & 66 & 1.2 \\
\hline Housewife & 3967 & 72.7 \\
\hline \multicolumn{3}{|c|}{ Major occupation of the head of $\mathrm{HH}$} \\
\hline Labor & 3003 & 55.1 \\
\hline Owner cultivator & 1947 & 35.7 \\
\hline Service/business & 507 & 9.4 \\
\hline \multicolumn{3}{|l|}{ Per capita income } \\
\hline Lowest tertile & 1899 & 34.8 \\
\hline Middle tertile & 1679 & 30.8 \\
\hline Highest tertile & 1865 & 34.4 \\
\hline
\end{tabular}

SC = Scheduled caste, $\mathrm{ST}=$ Scheduled tribe, $\mathrm{OBC}=$ Other backward community $\mathrm{HH}=$ Household 
Table 5. On bivariate analysis, discarding colostrum was observed to be significantly $(P<0.01)$ higher among mothers belonging to SC/ST communities, among illiterate women, illiteracy of head of HHs, lowest wealth index, women delivered at home and delivery conducted by untrained person.

Initiation of breastfeeding after 1 -h of childbirth was observed to be significantly $(P<0.01)$ higher among women of $\geq 30$ years of age, higher parity $(\geq 5)$, women belonging to SC/ST communities, illiteracy of self and husband, and home delivery and delivery conducted by untrained person.

On multivariate analysis, it was observed that the risk of discarding the colostrum was significantly $(P<0.01)$ higher among illiterate women, (OR: 1.6, 1.17-2.11) and among women belonging to lowest wealth index (OR: 1.4, 1.02-1.81). The risk of discarding the colostrum was 4 times higher (OR: 3.9, 3.02-4.98) among women whose delivery was conducted by untrained persons as compared to women whose delivery was conducted by medical doctors [Table 6].

Multivariate analysis for initiation of breast feeding after 1-h of childbirth was significantly $(P<0.01)$ higher among $\geq 30$ years women (OR: 1.9, 1.41-2.47) as compared to women $<26$ years, among illiterate women (OR: 1.4, 1.14-1.63) and the risk was 3 times (OR: 2.9; 2.37-3.50) higher among women whose delivery was conducted by untrained personnel [Table 6].

\begin{tabular}{|c|c|c|}
\hline Particulars & $n$ & Percentage \\
\hline \multicolumn{3}{|l|}{ Undergone ANC } \\
\hline Yes & 1651 & 78.5 \\
\hline No & 453 & 21.5 \\
\hline \multicolumn{3}{|l|}{ Number of ANCs } \\
\hline$<3$ & 886 & 42.1 \\
\hline$\geq 3$ & 765 & 36.4 \\
\hline No ANC & 453 & 21.5 \\
\hline \multicolumn{3}{|l|}{ Place of delivery } \\
\hline Home & 1173 & 21.4 \\
\hline Sub center & 251 & 4.6 \\
\hline Government hospital & 3693 & 67.8 \\
\hline Private hospital & 340 & 6.2 \\
\hline \multicolumn{3}{|l|}{ Delivery conducted by } \\
\hline Elders/untrained dais/others & 1108 & 20.3 \\
\hline ANM/LHV/TBA & 1540 & 28.2 \\
\hline Doctor & 2709 & 51.5 \\
\hline \multicolumn{3}{|l|}{ Colostrum's } \\
\hline Given & 5016 & 91.9 \\
\hline Discarded & 441 & 8.1 \\
\hline \multicolumn{3}{|l|}{ Time of initiation of breastfeeding } \\
\hline Within 1-h & 1440 & 26.4 \\
\hline After 1-h & 4017 & 73.6 \\
\hline
\end{tabular}

ANC = Antenatal care, ANM = Auxiliary nurse midwife, LHV = Lady health visitor, TBA $=$ Traditional birth attendant

\section{DISCUSSION}

Madhya Pradesh is one of the backward States in India with high infant and child mortality. According to sample registration survey 2011 report, ${ }^{[16]}$ infant mortality was highest in the State of Madhya Pradesh (67/1000 live births, National average 48/1000 live births), while maternal mortality was $269 / 100,000$ live births against the national average of 212/100,000 live births.

This was the first of kind large survey that the sample was drawn from all the 50 districts of the State. The study revealed high rates of illiteracy among mothers in Madhya Pradesh (49\% as against the national average of $35 \%$ ). The study showed that the utilization of ante-natal services for at least 3 times during pregnancy was $36 \%$, which was similar to that observed in District Level Household and Facility survey (34\%) in Madhya Pradesh ${ }^{[17]}$ and slightly lower

\begin{tabular}{|c|c|c|c|c|}
\hline \multirow[t]{2}{*}{ Particulars } & \multicolumn{2}{|c|}{$\begin{array}{l}<3 \text { antenatal } \\
\text { check-up }\end{array}$} & \multicolumn{2}{|c|}{ Home delivery } \\
\hline & OR & $95 \% \mathrm{Cl}$ & OR & $95 \% \mathrm{Cl}$ \\
\hline \multicolumn{5}{|l|}{ Age } \\
\hline $17-25$ & 1.0 & - & 1.0 & \\
\hline $26-30$ & 1.52 & $1.22-1.89$ & 1.31 & $1.14-1.50$ \\
\hline$\geq 30$ & 1.48 & $1.09-1.99$ & 1.80 & $1.50-2.15$ \\
\hline \multicolumn{5}{|l|}{ Parity } \\
\hline 1 and 2 & 1.0 & - & 1.0 & \\
\hline 3 & 1.45 & $1.12-1.85$ & 1.55 & $1.32-1.82$ \\
\hline 4 & 1.80 & $1.24-2.60$ & 2.01 & $1.61-2.49$ \\
\hline$\geq 5$ & 2.65 & $1.67-4.20$ & 2.94 & $2.32-3.71$ \\
\hline \multicolumn{5}{|l|}{ Community } \\
\hline $\mathrm{SC}+\mathrm{ST}$ & 1.74 & $1.30-2.33$ & 2.54 & 2.03-3.17 \\
\hline OBC & 1.17 & $0.87-1.57$ & 1.30 & $1.03-1.64$ \\
\hline Others & 1.0 & - & 1.0 & \\
\hline \multicolumn{5}{|l|}{ Type of family } \\
\hline Nuclear & 1.58 & $1.30-1.91$ & 1.0 & \\
\hline Extended nuclear & 1.40 & $1.05-1.87$ & 1.37 & $1.20-1.57$ \\
\hline Joint & 1.0 & - & 1.10 & $0.91-1.33$ \\
\hline \multicolumn{5}{|c|}{ Literacy status of woman } \\
\hline Illiterate & 2.90 & $2.34-3.60$ & 1.0 & \\
\hline $1^{\text {st }}-7^{\text {th }}$ class & 1.74 & $1.36-2.23$ & 2.31 & $1.97-2.71$ \\
\hline $8^{\text {th }}$ and above & 1.0 & - & 1.39 & $1.15-1.68$ \\
\hline \multicolumn{5}{|c|}{$\begin{array}{l}\text { Literacy status of head } \\
\text { of } \mathrm{HH}\end{array}$} \\
\hline Illiterate & 3.66 & $2.44-5.47$ & 1.0 & \\
\hline $1^{\text {st }-7^{\text {th }}}$ class & 2.62 & $1.71-4.01$ & 3.89 & $2.76-5.48$ \\
\hline $8^{\text {th }}-10^{\text {th }}$ class & 1.97 & $1.33-2.92$ & 2.30 & $1.61-3.28$ \\
\hline Inter and above & 1.0 & - & 1.66 & $1.17-2.34$ \\
\hline \multicolumn{5}{|l|}{ Wealth index (tertile) } \\
\hline Lowest & 1.94 & $1.56-2.40$ & 2.68 & $2.29-3.13$ \\
\hline Middle & 2.24 & $1.79-2.80$ & 1.81 & $1.54-2.13$ \\
\hline Highest & 1.0 & - & 1.0 & \\
\hline
\end{tabular}

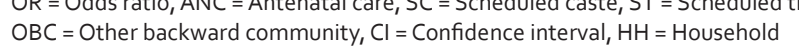


(41\%) as per NFHS-3 survey. ${ }^{[2]}$ The utilization of ANC services for at least 3 times was higher in the Southern States of India $80 \%$ in Karnataka and $96 \%$ in Tamil Nadu).${ }^{[3]}$ Multivariate analyses revealed that utilization of ANC practices for $<3$ times was higher among women with high parity, living in nuclear families, among illiterate women and lower SES. NFHS-3 also reported similar finding for Madhya Pradesh. ${ }^{[3,18,19]}$ The probable reasons cited for not utilizing or partial utilization of ANC services were unaware of the need $(14 \%)$, no faith and loss of wages (3\% each) and no ANCs held in village/place not accessible (4\% each). Unaware of need was more common $(68 \%)$ among illiterate women when compared to literate women $(32 \%)$.

Present study revealed that about $74 \%$ of mothers had institutional delivery, mostly at the government hospitals (67.8\%), but initiation of breastfeeding within 1-h of child birth among those delivered at hospital was very low (29.5\%). This finding revealed that even

Table 4: Multivariate regression analysis
for antenatal check-up and place of delivery
with sociodemographic particulars

\begin{tabular}{|c|c|c|c|c|}
\hline \multirow[t]{2}{*}{ Particulars } & \multicolumn{2}{|c|}{$\begin{array}{c}<3 \text { antenatal } \\
\text { check-up }\end{array}$} & \multicolumn{2}{|c|}{ Home delivery } \\
\hline & OR & $95 \% \mathrm{Cl}$ & OR & $95 \% \mathrm{Cl}$ \\
\hline \multicolumn{5}{|l|}{ Age } \\
\hline 17-25 & 1.0 & - & - & \\
\hline $26-30$ & 1.13 & $0.87-1.46$ & & \\
\hline$\geq 30$ & 0.62 & $0.41-0.95$ & & \\
\hline \multicolumn{5}{|l|}{ Parity } \\
\hline 1 and 2 & 1.0 & - & 1.0 & \\
\hline 3 & 1.18 & $0.88-1.58$ & 1.38 & $1.17-1.63$ \\
\hline 4 & 1.64 & $1.06-2.53$ & 1.75 & $1.40-2.19$ \\
\hline$\geq 5$ & 2.51 & $1.41-4.49$ & 2.30 & $180-2.93$ \\
\hline \multicolumn{5}{|l|}{ Community } \\
\hline$S C+S T$ & - & - & 1.54 & $1.21-1.97$ \\
\hline $\mathrm{OBC}$ & - & - & 1.03 & $0.81-1.32$ \\
\hline Others & & & 1.0 & \\
\hline \multicolumn{5}{|l|}{ Type of family } \\
\hline Nuclear & 1.31 & $1.07-1.61$ & - & - \\
\hline Extension nuclear & 1.26 & $0.94-1.70$ & - & - \\
\hline Joint & 1.0 & & - & - \\
\hline \multicolumn{5}{|c|}{ Literacy status of woman } \\
\hline Illiterate & 2.32 & $1.82-2.95$ & - & - \\
\hline $1^{\text {st }}-7^{\text {th }}$ class & 1.53 & $1.18-1.98$ & - & - \\
\hline $8^{\text {th }}$ - and above & 1.0 & & - & - \\
\hline \multicolumn{5}{|c|}{$\begin{array}{l}\text { Literacy status of head } \\
\text { of } \mathrm{HH}\end{array}$} \\
\hline Illiterate & - & - & 1.99 & $1.38-2.87$ \\
\hline $1^{\text {st }}-7^{\text {th }}$ class & - & - & 1.47 & $1.01-2.12$ \\
\hline $8^{\text {th }}-10^{\text {th }}$ class & - & - & 1.26 & $0.89-1.79$ \\
\hline Inter and above & & & 1.0 & \\
\hline \multicolumn{5}{|l|}{ Wealth index (tertile) } \\
\hline Lowest & 1.27 & $1.01-1.62$ & 1.71 & $1.42-2.04$ \\
\hline Middle & 1.77 & $1.40-2.24$ & 1.40 & $1.18-1.67$ \\
\hline Highest & 1.0 & - & 1.0 & - \\
\hline
\end{tabular}

SC = Scheduled caste, $\mathrm{ST}=$ Scheduled tribe, $\mathrm{OBC}=$ Other backward community, $\mathrm{ANC}=$ Antenatal care, $\mathrm{HH}=$ Household, $\mathrm{OR}=$ Odds ratio, $\mathrm{Cl}=$ Confidence interval medical persons needs to be educated for encouraging these practices in case of hospital delivery. Multivariate analysis revealed that home delivery was significantly higher among women with high parity, among schedules caste and scheduled tribe women and lower SES. Mumbare and Rege and Pradhan et al. also reported lower rates of institutional deliveries among women belonging to low SES, among illiterate parents and among three-generation families. ${ }^{[18,19]}$

\begin{tabular}{|c|c|c|c|c|}
\hline \multirow[t]{2}{*}{ Particulars } & \multicolumn{2}{|c|}{$\begin{array}{l}\text { Discarded } \\
\text { colostrum }\end{array}$} & \multicolumn{2}{|c|}{$\begin{array}{c}\text { Breastfeeding } \\
>1-h\end{array}$} \\
\hline & OR & $95 \% \mathrm{Cl}$ & OR & $95 \% \mathrm{Cl}$ \\
\hline \multicolumn{5}{|l|}{ Age } \\
\hline $17-25$ & 1.0 & - & 1.0 & - \\
\hline $26-30$ & 1.14 & $0.91-1.42$ & 1.14 & $1.00-1.31$ \\
\hline$\geq 30$ & 0.99 & $0.72-1.36$ & 1.79 & $1.45-2.22$ \\
\hline \multicolumn{5}{|l|}{ Parity } \\
\hline 1 and 2 & 1.0 & - & 1.0 & - \\
\hline 3 & 1.03 & $0.79-1.34$ & 0.95 & $0.81-1.12$ \\
\hline 4 & 1.09 & $0.75-1.59$ & 1.16 & $0.91-1.48$ \\
\hline$\geq 5$ & 1.30 & $0.89-1.91$ & 1.74 & $1.29-2.34$ \\
\hline \multicolumn{5}{|l|}{ Community } \\
\hline$S C+S T$ & 2.01 & $1.41-2.88$ & 1.34 & $1.10-1062$ \\
\hline OBC & 1.03 & $0.71-1.52$ & 1.03 & $0.85-1.25$ \\
\hline Others & 1.0 & - & 1.0 & - \\
\hline \multicolumn{5}{|l|}{ Type of family } \\
\hline Nuclear & 0.80 & $0.65-0.99$ & 0.94 & $0.83-1.07$ \\
\hline Extension nuclear & 0.93 & $0.69-1.25$ & 1.01 & $0.84-1.22$ \\
\hline Joint & 1.0 & - & 1.0 & - \\
\hline \multicolumn{5}{|l|}{$\begin{array}{l}\text { Literacy status of the } \\
\text { woman }\end{array}$} \\
\hline Illiterate & 2.24 & $1.72-2.94$ & 1.55 & $1.35-1.79$ \\
\hline $1^{\text {st }} 7^{\text {th }}$ class & 1.39 & $1.01-1.93$ & 1.33 & $1.13-1.58$ \\
\hline $8^{\text {th }}$ class and above & 1.0 & - & 1.0 & - \\
\hline \multicolumn{5}{|l|}{$\begin{array}{l}\text { Literacy status of head } \\
\text { of } \mathrm{HH}\end{array}$} \\
\hline Illiterate & 1.77 & $1.09-2.86$ & 1.67 & $1.28-2.16$ \\
\hline $1^{\text {st }-7^{\text {th }}}$ class & 1.26 & $0.76-2.09$ & 1.76 & $1.34-2.32$ \\
\hline $8^{\text {th }}-10^{\text {th }}$ & 0.99 & $0.61-1.60$ & 1.12 & $0.98-1.62$ \\
\hline HSC and above & 1.0 & - & 1.0 & - \\
\hline \multicolumn{5}{|l|}{ Wealth index (tertile) } \\
\hline Lowest & 2.32 & $1.81-2.97$ & 0.98 & $0.85-1.13$ \\
\hline Middle & 1.23 & $0.93-1.62$ & 1.35 & $1.10-1.57$ \\
\hline Highest & 1.0 & - & 1.0 & - \\
\hline \multicolumn{5}{|l|}{ Place of delivery } \\
\hline Home/sub-center & 2.87 & $2.36-3.50$ & 1.97 & $1.69-2.30$ \\
\hline Institutional & 1.0 & - & 1.0 & - \\
\hline \multicolumn{5}{|l|}{ Delivery conducted by } \\
\hline Untrained person & 4.66 & $3.65-5.93$ & 2.92 & $2.43-3.53$ \\
\hline TBA/ANM/LHV & 2.19 & $1.69-2.82$ & 1.50 & $1.30-1.72$ \\
\hline Doctor & 1.0 & - & 1.0 & - \\
\hline
\end{tabular}

TBA = Traditional birth attendant, ANM = Auxiliary nurse midwife, LHV = Lady health visitor, $\mathrm{SC}=$ Scheduled caste, $\mathrm{ST}=$ Scheduled tribe, $\mathrm{OBC}=$ Other backward community, IYCF = Infant and young child feeding, $\mathrm{Cl}=$ Confidence interval 


\begin{tabular}{|c|c|c|c|c|}
\hline \multirow[t]{2}{*}{ Particulars } & \multicolumn{2}{|c|}{$\begin{array}{l}\text { Discarded } \\
\text { colostrum }\end{array}$} & \multicolumn{2}{|c|}{$\begin{array}{l}\text { Breast feeding } \\
\text { after 1-h }\end{array}$} \\
\hline & OR & $95 \% \mathrm{Cl}$ & OR & $95 \% \mathrm{Cl}$ \\
\hline \multicolumn{5}{|l|}{ Age } \\
\hline $17-25$ & - & - & 1.0 & - \\
\hline $26-29$ & - & - & 1.15 & $0.98-1.36$ \\
\hline$\geq 30$ & - & - & 1.87 & $1.41-2.47$ \\
\hline \multicolumn{5}{|l|}{ Parity } \\
\hline 1 and 2 & - & - & 1.0 & - \\
\hline 3 & - & - & 0.74 & $0.62-0.89$ \\
\hline 4 & - & - & 0.74 & $0.55-0.97$ \\
\hline$\geq 5$ & - & - & 0.83 & $0.57-1.20$ \\
\hline \multicolumn{5}{|l|}{ Community } \\
\hline$S C+S T$ & 1.13 & $0.76-1.68$ & 1.18 & $0.95-1.47$ \\
\hline OBC & 0.81 & $0.54-1.20$ & 0.96 & $0.78-1.17$ \\
\hline Others & 1.0 & - & 1.0 & - \\
\hline \multicolumn{5}{|c|}{ Literacy status of woman } \\
\hline Illiterate & 1.57 & $1.17-2.11$ & 1.37 & $1.14-1.63$ \\
\hline $1^{\text {st }-7^{\text {th }}}$ class & 1.30 & $0.93-1.82$ & 1.25 & $1.04-1.49$ \\
\hline $8^{\text {th }}$ class and above & 1.0 & - & 1.0 & - \\
\hline \multicolumn{5}{|l|}{ Wealth index (tertile) } \\
\hline Lowest & 1.36 & $1.02-1.81$ & 0.62 & $0.52-0.74$ \\
\hline Middle & 0.90 & $0.67-1.20$ & 1.04 & $0.88-1.23$ \\
\hline Highest & 1.0 & - & 1.0 & - \\
\hline \multicolumn{5}{|l|}{ Delivery conducted by } \\
\hline Untrained person & 3.88 & $3.02-4.98$ & 2.88 & $2.37-3.50$ \\
\hline ANM/LHV/TBA & 2.02 & $1.56-2.62$ & 1.56 & $1.35-1.80$ \\
\hline Doctor & 1.0 & & 1.0 & \\
\hline
\end{tabular}

$\mathrm{OR}=$ Odds ratio, $\mathrm{ANM}=$ Auxiliary nurse midwife, $\mathrm{LHV}=$ Lady health visitor, $\mathrm{SC}=$ Scheduled caste, $\mathrm{ST}=$ Scheduled tribe, $\mathrm{OBC}=$ Other backward community, IYCF = Infant and young child feeding, $\mathrm{Cl}=$ Confidence interval

Infant and young child feeding practices are the important determinants of nutritional status of below 5 years children. In the present study, it was observed that only $26 \%$ newborn received breastfeeding within 1 -h of birth, while about $9 \%$ received breast feeding after $24 \mathrm{~h}$ of birth. Early initiation of breastfeeding is important for establishing successful lactation as well as for providing the colostrum (mother's first milk) to the baby. ${ }^{[20]}$ Colostrums contain antiinfective substances which protect the baby from infectious diseases such as diarrhea and ARI to which the child might be exposed during the $1^{\text {st }}$ few weeks after birth which are the important reasons for infant mortality and morbidity. ${ }^{[21,22]}$ Multivariate analysis revealed that discarding colostrum and late initiation (after 1-h of birth) was significantly higher among illiterate women and among women whose delivery was conducted by untrained personnel. These findings are similar to that reported in other studies. ${ }^{[23,24]}$

It was also observed that the utilization of health services was higher among literate mothers compared to illiterate as observed in other studies. ${ }^{[25]}$ This is because better-educated women are, more aware about their health, know more about availability of maternal health care services and use this awareness and information in accessing the health care services.

\section{CONCLUSION}

As it was observed that antenatal care, delivery and IYCF practices were associated with literacy status of women, community and wealth index and person conducting delivery. Thus improving the literacy of women along with SES, deliveries by trained health personnel and improved information, education and communication services can improve these practices and thus nutritional status of under 5 years children.

\section{ACKNOWLEDGMENT}

Authors are thankful to the Principal Secretary, Deputy and Joint Secretaries, Director and Deputy Director, Women and Child Development and Social Justice Department, Ministry of Health and Family Welfare, Government of Madhya Pradesh for providing an opportunity to carry out this study. We are also thankful to Districts Project Officers, Child Development Project Officers, Supervisors, Anganwadi Workers and Accredited Social Health Activists worker (Health functionaries) in the execution of the survey. Our sincere thanks to the entire field staff for their sincere efforts in the data collection. We also thank Mr. G. Manohar Reddy, Research Officer, Mr. Raghunath Babu, Technical Assistant, Mrs. G. Madhavi, Technician, secretarial staff and others for their help.

\section{REFERENCES}

1. Venkatachalam PS. Maternal nutritional status and its effect on the new born. Bull World Health Organ 1962;26:193-201.

2. National Population Policy, 2000. Available from: http://www.india. unfpa.org/drive/NationalPopulation-policy2000.pdf. [Last accessed on 2012 Jun 27].

3. International Institute for Population Sciences (IIPS) and Macro International. National Family Health Survey (NFHS-3), 2005-06: India. Vol. I. Mumbai: IIPS; 2007.

4. United Nations Millenium Development Goals; 2012. p. 10-8. Un.org. http:/ www.un.org/milleniumgoals/poverty.shtml. [Last accessed on 2008 May 20].

5. Gabrysch S, Campbell OM. Still too far to walk: literature review of the determinants of delivery service use. BMC Pregnancy Childbirth 2009;9:34.

6. Becker S, Peters DH, Gray RH, Gultiano C, Black RE. The determinants of use of maternal and child health services in Metro Cebu, the Philippines. Health Transit Rev 1993;3:77-89.

7. Andersen RM, Newman JF. Social and individual determinants of medical care utilization in the United States. Milbank Mem Q 1973;51:95-124.

8. Magadi MA, Madise NJ, Rodrigues RN. Frequency and timing of antenatal care in Kenya: Explaining the variations between women of different communities. Soc Sci Med 2000;51:551-61.

9. Kesterton AJ, Cleland J, Sloggett A, Ronsmans C. Institutional delivery in rural India: The relative importance of accessibility and economic status. BMC Pregnancy Childbirth 2010;10:30.

10. Stephenson R, Tsui AO. Contextual influences on reproductive health service use in Uttar Pradesh, India. Stud Fam Plann 2002;33:309-20.

11. Fiedler JL. A review of the literature on access and utilization of medical care with special emphasis on rural primary care. Soc Sci Med C 1981;15:129-42.

12. Hingson R, Lin N, Hingson RA. Achieving higher immunization receptivity. Public Health Rev 1976;6:93-117.

13. Filmer D, Pritchett LH. Estimating wealth effects without expenditure data - or tears: An application to educational enrollments in states of India. Demography 2001;38:115-32.

14. Rutstein SO, Kiersten J. The DHS Wealth Index. DHS Comparative Reports 6. Calverton, Maryland: ORC Macro; 2004. 
15. IBM SPSS 17.0 version. United States; 2010.

16. Available from: http://www.censusindia.gov.in/vital_statistics/SRS_Bulletin/ MMR_release_070711.pdf. [Last accessed on 2012 Feb 06].

17. International Institute for Population Sciences (IIPS). District Level Household and Facility Survey (DLHS-3), 2007-08: India: Key Indicators: States and Districts. Mumbai: IIPS; 2010.

18. Mumbare SS, Rege R. Ante natal care services utilization, delivery practices and factors affecting them in tribal area of North Maharashtra. Indian J Community Med 2011;36:287-90.

19. Pradhan PM, Bhattarai S, Paudel IS, Gaurav K, Pokharel PK. Factors contributing to antenatal care and delivery practices in Village Development Committees of Ilam district, Nepal. Kathmandu Univ Med J (KUMJ) 2013;11:60-5.

20. Saadeh R, Akré J. Ten steps to successful breastfeeding: A summary of the rationale and scientific evidence. Birth 1996;23:154-60.

21. Chandra RK. Immunological aspects of human milk. Nutr Rev 1978;36:265-72.
22. Welsh JK, May JT. Anti-infective properties of breast milk. J Pediatr 1979;94:1-9.

23. Sinclair S, Houston V, Shields K, Snelling S. Breastfeeding Practices in Northern Ontario. Northern Ontario Perinatal and Child Health Survey; 2003.

24. Socioeconomic Factors Related to Infant Feeding Practices in Durham Region. Infant Feeding Surveillance System; 2012.

25. Elo IT. Utilization of maternal health-care services in Peru: The role of women's education. Health Transit Rev 1992;2:49-69.

How to cite this article: Meshram II, Rao KM, Reddy CG, Krishna KS, Venkaiah K, Laxmaiah A, et al. Predictors of ante-natal care, delivery and infant feeding practices among rural women in Madhya Pradesh, India. Int J Med Public Health 2014;4:385-91.

Source of Support: Nil, Conflict of Interest: None declared.

Announcement

\section{iPhone App}

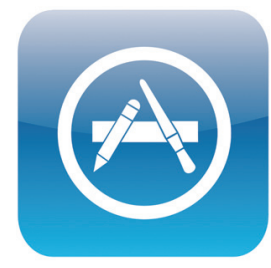

A free application to browse and search the journal's content is now available for iPhone/iPad. The application provides "Table of Contents" of the latest issues, which are stored on the device for future offline browsing. Internet connection is required to access the back issues and search facility. The application is Compatible with iPhone, iPod touch, and iPad and Requires iOS 3.1 or later. The application can be downloaded from http:// itunes.apple.com/us/app/medknow-journals/id458064375?ls $=18 \mathrm{mt}=8$. For suggestions and comments do write back to us. 